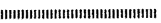 \\ $\mathrm{Ni}-\mathrm{Cr}-\mathrm{W}$ 合金の低サイクル疲労挙動におよぼす 高温ガス炉近似へリウムの影響
}

\author{
古屋 一夫*・佐藤 幸一 ${ }^{* 2} \cdot$ 貝沼 紀夫*3 $\cdot$ 吉田平太郎 ${ }^{* 4}$
}

\section{The Role of Simulated HTGR Helium on the Low Cycle Fatigue Behavior of $\mathrm{Ni}-\mathrm{Cr}-\mathrm{W}$ Alloys}

Kazuo Furuya, Kouichi SAto, Toshio KaInuma and Heitarou YoshidA

\begin{abstract}
Synopsis :
Low cycle fatigue behavior of two Ni-Cr-W alloys (Ni-15Cr-25W (KSN) and Ni-23Cr-18W(113MA)) was investigated at $1273 \mathrm{~K}$ in the simulated High Temperature Gas-cooled Reactor (HTGR) helium, He-2. Both alloys showed little cyclic hardening in fatigue tests and failed in a completely intergranular manner. Although the fatigue life $\left(N_{f}\right)$ of $113 \mathrm{MA}$ was a little longer than that of KSN, observed intergranular fractures indicated that the fatigue properties of both alloys were severely influenced by impurities in $\mathrm{He}-2$.

As well as in $\mathrm{He}-2$, fatigue tests of KSN and 113MA were carried out in pure $\mathrm{He}$, air and vacuum. The results clearly showed that, regardless of the concentration of reactive gases, both alloys failed intergranularly with short $N_{f} \mathrm{~s}$ in gaseous environments, as compared with the transgranular fracture with long $N_{f}$ in vacuum. A minor effect of impurity contents was shown as an increase in $N_{f}$ with substituting the environment from air then $\mathrm{He}-2$ to pure $\mathrm{He}$. It is considered from these behaviors that the fatigue fractures were affected by residual oxygen gas in the environments penetrating into specimens along the grain boundaries.
\end{abstract}

\section{1. 緒言}

高温ガス炉から $1200 \mathrm{~K}$ 程度の $\mathrm{He}$ を取り出し, 発 電のほかに製鉄などの幅広い利用を実現するためには, 中間熱交換器用耐熱合金の開発が重要な課題の一つであ る. この合金は微量の不純物 $\left(\mathrm{H}_{2}, \mathrm{H}_{2} \mathrm{O}, \mathrm{CO}, \mathrm{CO}_{2}\right.$, $\left.\mathrm{CH}_{4}\right)$ を含む腐食性 $\mathrm{He}$ 雾囲気中で $1273 \mathrm{~K}, 5$ 万 $\mathrm{h}$ 以 上使用されるため, 高温における機械的性質とそれにお よぼす環境効果の面から開発を進める必要がある1). 我 が国では高温ガス炉定常運転時を想定し, クリープ破断 特性に着目した合金開発が国家的プロジェクトとして推 進され, 上記条件下で $9.8 \mathrm{MN} / \mathrm{m}^{2}$ 以上の強度を有する 2 種類の Ni-Cr-W 合金がすでに開発されている2)3). しかしながら高温ガス炉の起動停止にともなつて生じる 疲労損傷に対するこれら合金の挙動については, 十分な 検討が行われていない.

一般に金属材料の疲労特性は試験環境に大きく影響さ れ, 真空中や不活性ガス中では大気中よりも良好な特性 を示すことが知られている4). この原因の一つは疲労 き裂の発生と伝播におよぼす腐食の効果である．高温大
気中などの腐食環境では, 試験片表面にしばしば脆い酸 化物層が生成し, 疲労き裂の発生を促進する.一方, き 裂の伝播に対しては，き裂内面に生成した腐食物がき裂 の安定化をもたらし，き裂先端のそれは伀播を促進す る.このため腐食環境下での疲労寿命は一般に短い、し かし高温ガス炉 $\mathrm{He}$ は低酸化ポテンシャルという特異な 環境であるため，合金の腐食挙動は大気中とは全く異な $\eta^{6) 7)}, \mathrm{He}$ 雾囲気中での疲労挙動を推測する手段はほと んどないといえる.

そこで本研究では, 中間熱交換器用合金として開発さ れた 2 種類の $\mathrm{Ni}-\mathrm{Cr}-\mathrm{W}$ 合金 $\left(\mathrm{KSN}^{2)}, 113 \mathrm{MA}^{3)}\right)$ につ いて, 高温ガス炉定常運転時の炉出口組成を近似した第 $2 \mathrm{He}$ ガス中で低サイクル疲労試験を行い, 両合金の疲 労特性を明らかにすることを目的とした.ささらに，得ら れた結果を疲労挙動におよほす試験環境の効果の面から 考察する目的で, 純 $\mathrm{He}$ 中, 真空中, 大気中でも実験を 行い, 4 種類の環境での挙動の差を比較検討した.

\section{2. 試料および実験方法}

試料の化学組成を Table 1 に示す. 両合金とも $\mathrm{Cr}$

昭和 58 年 4 月本会講演大会にて発表 昭和 59 年 4 月 2 日受付 (Received Apr. 2, 1984)

* 金属材料技術研究所筑波支所 (Tsukuba Laboratories, National Research Institute for Metals, 1-2-1

Sengen Sakuramura Niihari-gun Ibaraki pref.)

*2 金属材料技術研究所 (National Research Institute for Metals)

*3 金属材料技術研究所筑波支所 工博 (Tsukuba Laboratories, National Research Institute for Metals)

*4 金属材料技術研究所工博 (National Research Institute for Metals) 
Table 1. Chemical compositions of alloys (wt $\%$ ).

\begin{tabular}{lcccccccc}
\hline Alloy & $\mathrm{C}$ & $\mathrm{Cr}$ & $\mathrm{W}$ & $\mathrm{Zr}$ & $\mathrm{Ti}$ & $\mathrm{Al}$ & $\mathrm{Nb}$ & $\mathrm{Ni}$ \\
\hline 113MA & 0.056 & 23.53 & $\mathbf{1 7 . 6 5}$ & 0.031 & 0.510 & $-\overline{130}$ & $\overline{0}$ & Bal. \\
KSN & 0.027 & $\mathbf{1 4 . 8 5}$ & $\mathbf{2 3 . 6 1}$ & 0.050 & 0.360 & 0.1300 & Bal. \\
\hline
\end{tabular}



Fig. 1. Profile of low cycle fatigue specimen $(\mathrm{mm})$.

とWを 15〜25\% 固溶させた $\mathrm{Ni}$ 基合金であり， $1573 \mathrm{~K}$ で $1 \mathrm{~h}$ の固溶化処理を行い $\gamma$ 単相としてある. 結晶粒 径は約 $200 \mu \mathrm{m}$ である.

低サイクル疲労試験に使用した試験片形状を Fig. 1 に示す. 試験機はターボ分子ポンプで $10^{-7} \mathrm{~Pa}$ まで真 空排気できる雾囲気槽をとりつけた, 油圧サーボ型引張 圧縮試験装置である. 荷重測定は雾囲気槽外のロードセ ルで行い, 変位は平行部に標点間距離 $10 \mathrm{~mm}$ の軸方向 伸び計を押しあてて行つた. 試験はこの伸び計を用いた ひずみ制御で行い, 波形は平均值がゼ口の三角波で，ひ ずみ速度は $1 \times 10^{-3} \mathrm{~s}^{-1}$ である. 試験した全ひずみ範囲 は 0.003 から 0.02 までの 6 水準である. また試験片の 加熱は高周波誘導加熱を用い, 平行部長さ方向の温度差 を $\pm 10 \mathrm{~K}$ 以内となるように加熱コイルをセットして行 つた. 試験温度は $1273 \mathrm{~K}$ である.

試験環境のうち, 第 $2 \mathrm{He}$ と純 $\mathrm{He}$ 雾囲気は槽内を 排気した後, $\mathrm{He}$ を注入し, 圧力を $39.2 \mathrm{kPa}$, 流量を $5 \times 10^{-9} \mathrm{~m}^{3} \mathrm{~s}^{-1}$ とした. この時第 $2 \mathrm{He}$ ガスの供給は循 環式の $\mathrm{He}$ ループによつて行つたが, 純 $\mathrm{He}$ ガスでは ボンベ $\mathrm{He}$ を液体窒素トラップを通過させ, 十分純化し た後供給した. Table 2 にはガスクロマトグラフと水 分計で測定した試験中の不純物濃度を示した. 検出限界 を考虑すると, 第 $2 \mathrm{He}$ 中の不純物濃度の変動は小さい
Table 2. Chemical compositions of HTGR helium gas and pure helium gas (ppm by volume).

\begin{tabular}{lccccccc}
\hline & $\mathrm{H}_{2} \mathrm{O}$ & $\mathrm{H}_{2}$ & $\mathrm{CH}_{4}$ & $\mathrm{CO}$ & $\mathrm{CO}_{2}$ & $\mathrm{~N}_{2}$ & $\mathrm{O}_{2}$ \\
\hline $\mathrm{He}-2$ & $3 \pm 1$ & $300 \pm 10$ & $4 \pm 1$ & $100 \pm 10$ & $1 \pm 1$ & $<1$ & $\mathrm{ND}$ \\
PURE & ND & ND & ND & ND & ND & $<1$ & ND \\
\hline
\end{tabular}

が，逆に純 He 中の場合，不純物が全く含まれていない と結論することはできない。

真空中の試験では, 10-7 Pa まで排気した後試験片の 加熱を行つたが, 後述するよらに, $1273 \mathrm{~K}$ では試験片 からの Cr の蒸発量が多く, 真空度は $10^{-6} \mathrm{~Pa}$ であつ た.また，大気中の試験において湿度調節は行つていな W.

なお，本実験では所定の雾囲気となつた後で加熱を行 い，その後試験装置が定常状態となるまで $1273 \mathrm{~K}$ で約 $3 \mathrm{~h}$ 無負荷で保持してから試験を開始した.

破断後の試験片観察は走査型電子顕微鏡 (SEM) を用 いて行い, 合金元素の濃度分布はエネルギー分散型 $\mathrm{X}$ 線 マイクロアナライザ (EDS) で行つた.

\section{3. 実 験 結 果}

\section{1 第 2 He 中における低サイクル疲労挙動}

Fig. 2 にはひずみ変形のくり返しにともなら，応 カ・ひずみループの変化の一例を KSN について示し， Fig. 3 にはくり返し数 $(N)$ と応力幅 $(\Delta \sigma)$ の関係を まとめて示した. 第 1 回目の変形時に引張側で顕著な降 伏現象が観察されたが，これは試験開始以前の $1273 \mathrm{~K}$ での加熱において炭化物の析出が起こり ${ }^{8)}$, 時効硬化し たためであろう．次に特徵的なことは, 試料が溶体化材 であるにもかかわらず，第 2 サイクル以後全くくり返し 硬化せず，すぐに定常的な応力・ひずみループを形成す ることである.この傾向は両合金とも同様であるので, 本実験ではこの時の応力ひずみ関係を試験の代表值とし た.さらにNを増加すると， $\Delta \sigma$ はしだいに低下し，同

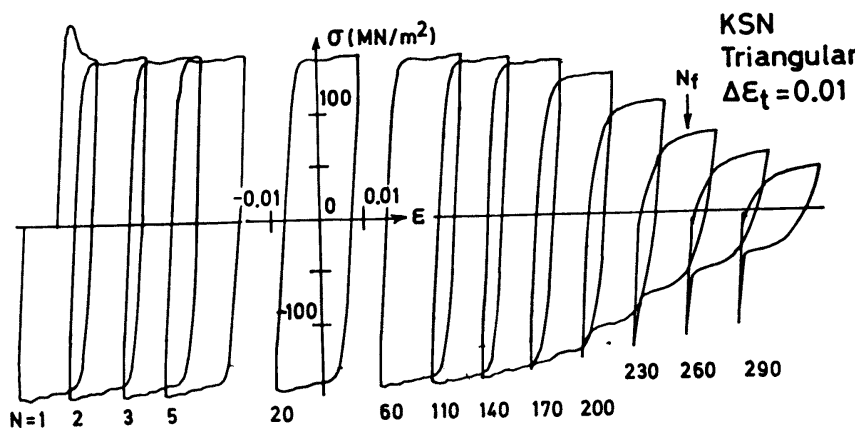

Fig. 2. Typical example of stress-strain loops obtained from a low cycle fatigue test of $\mathrm{KSN}$ at $1273 \mathrm{~K}$ in $\mathrm{He}-2$. 
時にループは対称性を失い，疲労き裂の発生を示すよう になる．そこで引張応力が定常時のそれの $50 \%$ になつ たくり返し数を破断寿命 $\left(N_{f}\right)$ と定義し，以下の解析で 使用した.しかし, 試験は $N_{f}$ 以後も可能なかぎり続行

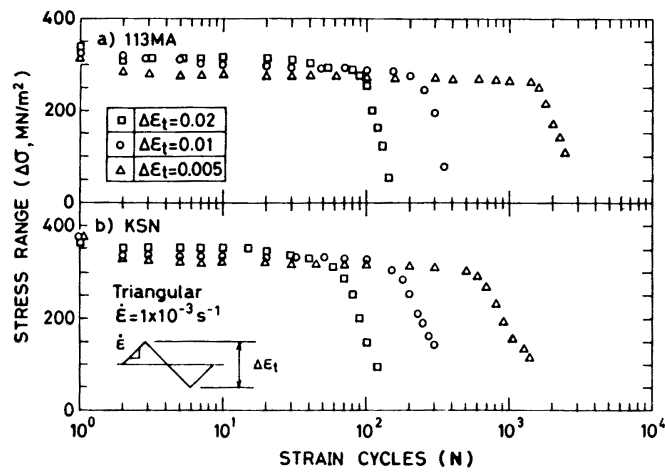

Fig. 3. Changes in stress range $(\Delta \sigma)$ of $\mathrm{KSN}$ and 113MA with increasing strain cycles $(N)$ at $1273 \mathrm{~K}$ in $\mathrm{He}-2$.

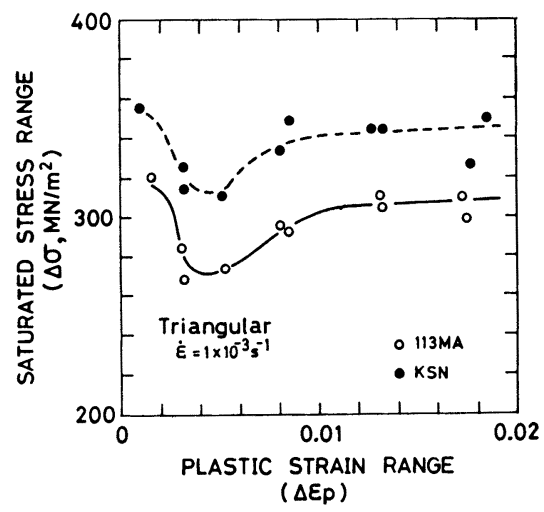

Fig. 4. Relation between stress range $(\Delta \sigma)$ and plastic strain range $\left(\Delta \varepsilon_{p}\right)$ for $\mathrm{KSN}$ and 113MA at $1273 \mathrm{~K}$ in $\mathrm{He}-2$.
し, 疲労さ裂を試験片全面に進展させた後中止し, 破面 観察に供した。

定常時の $\Delta \sigma$ とその時の塑性ひずみ幅 $\left(\Delta \varepsilon_{p}\right)$ の関係 を Fig. 4 に示す. KSN は $113 \mathrm{MA}$ よりも全体的に大 きな $\Delta \sigma$ を示すが，曲線の形状は両合金とも同様であつ た.すなわち, $\Delta \sigma$ は $\Delta \varepsilon_{p}$ が約 0.004 の時に極小值を とり, $\Delta \varepsilon_{p}>0.01$ の範囲ではほぼ一定值となつた. $\Delta \varepsilon_{p}$ $=0.002$ 近傍で大きな $\Delta \sigma$ を示した理由は, Fig. 2 で 示した降伏現象に起因するものであろう.

破断くり返し数 $\left(N_{f}\right)$ と各ひずみ幅の関係を Fig. 5 に示す.ここで弾性ひずみ幅 $\left(\Delta \varepsilon_{e}\right)$ は $\Delta \varepsilon_{t}$ と $\Delta \varepsilon_{p}$ の 差で与えられている. $\Delta \varepsilon_{e}-N_{f}$ と $\Delta \varepsilon_{p}-N_{f}$ の関係は両対 数で示すと直線で近似できるため, Table 3 にはこの直 線の定数を示した.オーステナイトステンレス鋼に関し て得られている同様のデータでは， $\beta$ 值は大気中では $0.6^{9)}$ ，真空中では 0.54)5) に近い值を示すが, 本実験の $\beta$ 值は環境が低酸化ポテンシャルであるにもかかわらず, 大気中の結果に近いか，それより大きな值を示した.

SEM による代表的な破面の全体写真を Photo. 1 に 示す. 両合金とも全体的に粒界破壊が支配的であり, 疲 労き裂の発生点を識別することはできなかつた。一般的 には，低サイクル疲労における粒界破壊はひずみ速度が 遅く，クリープの影響がある場合に支配的となると報告 されているが910)，本実験のひずみ速度はこれらの場合 と比較すると十分速く, むしろ試験環境の効果と考えた 方が合理的であろう.

Table 3. Values of constants for low cycle fatigue equations of 113MA and KSN at $1273 \mathrm{~K}$ in He-2.

\begin{tabular}{lccccc}
\hline \multirow{2}{*}{ Alloy } & \multicolumn{2}{c}{$\Delta \varepsilon_{e} \cdot \mathrm{N}_{f}{ }^{\alpha}=\mathrm{C}_{1}$} & & \multicolumn{2}{c}{$\Delta \varepsilon_{p} \cdot \mathrm{N}_{f}{ }^{\theta}=\mathrm{C}_{2}$} \\
\cline { 2 - 3 } \cline { 5 - 6 } & \multicolumn{1}{c}{$\alpha$} & $\mathrm{C}_{1}$ & & $\beta$ & $\mathrm{C}_{2}$ \\
\hline 113MA & 0.0453 & $2.17 \times 10^{-3}$ & 0.607 & 0.292 \\
KSN & 0.0049 & $1.86 \times 10^{-3}$ & 0.871 & 0.953 \\
\hline
\end{tabular}

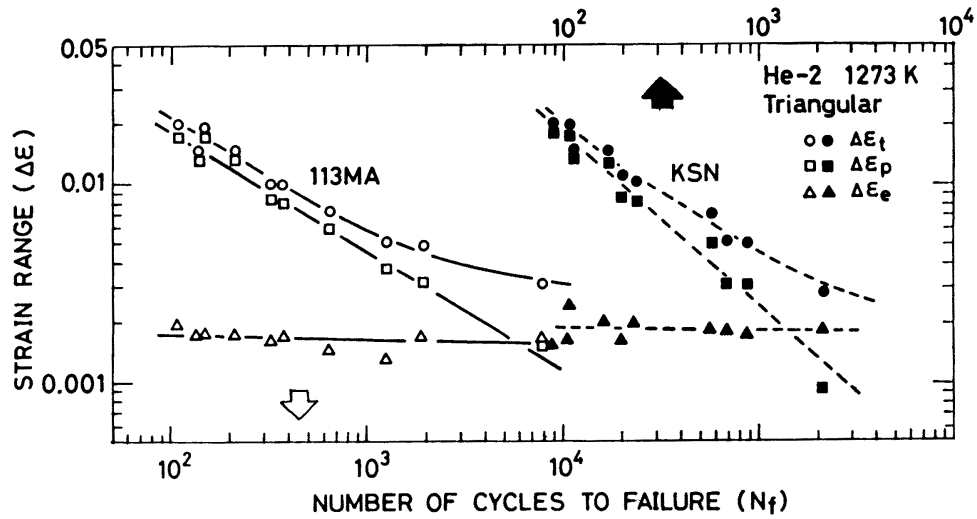

Fig. 5. Relations between strain ranges $\left(\Delta \varepsilon_{t}, \Delta \varepsilon_{p}\right.$ and $\left.\Delta \varepsilon_{e}\right)$ and number of cycles to failure $\left(N_{f}\right)$ for $\mathrm{KSN}$ and $113 \mathrm{MA}$ at $1273 \mathrm{~K}$ in $\mathrm{He}-2$. 

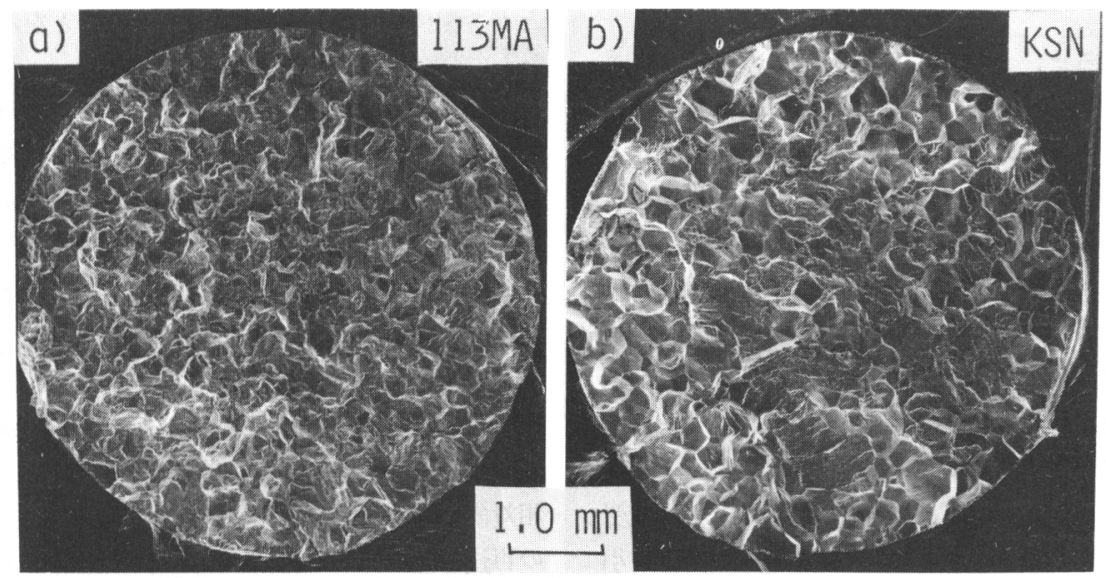

a) $113 \mathrm{MA}$ and b) KSN.

Photo. 1. Fracture surfaces after fatigue tests at $\Delta \varepsilon_{t}=0.01$ with triangular waves at $1273 \mathrm{~K}$ in $\mathrm{He}-2$.

Table 4. Low cycle fatigue data for KSN and $113 \mathrm{MA}$ at the total strain range $\left(\Delta \varepsilon_{t}\right)$ of 0.01 at $1273 \mathrm{~K}$ in various environments.

\begin{tabular}{|c|c|c|c|c|c|c|c|c|c|}
\hline \multirow{2}{*}{ Alloy } & \multirow{2}{*}{$\begin{array}{l}\text { Environ- } \\
\text { ment }\end{array}$} & \multirow{2}{*}{$\begin{array}{l}\text { Plastic } \\
\text { strain } \\
\text { range } \\
\Delta \varepsilon_{p}(\%)\end{array}$} & \multirow{2}{*}{$\begin{array}{l}\text { Elastic } \\
\text { strain } \\
\text { range } \\
\Delta \varepsilon_{e}(\%)\end{array}$} & \multirow{2}{*}{$\begin{array}{l}\text { Stress } \\
\text { range } \\
\Delta \sigma \\
\left(\mathrm{MN} / \mathrm{m}^{2}\right)\end{array}$} & \multicolumn{4}{|c|}{ Number of cycles } & \multirow{2}{*}{$\begin{array}{l}\text { Total } \\
\text { time for } \\
\text { test } \\
t(\mathrm{~h})\end{array}$} \\
\hline & & & & & $N \sigma^{*}$ & $N_{c}^{* *}$ & $N_{f}^{*}$ & $N_{t} * * *$ & \\
\hline \multirow[t]{5}{*}{$113 \mathrm{MA}$} & $\mathrm{He}-2$ & 0.84 & 0.16 & 293 & 223 & 230 & 324 & 393 & 5.18 \\
\hline & $\mathrm{He}-2$ & 0.80 & 0.17 & 296 & 254 & 248 & 358 & 405 & 5. 25 \\
\hline & VACUUM & 0.82 & 0.17 & 284 & 1550 & 1050 & 11550 & 16400 & 94.11 \\
\hline & AIR & 0.82 & 0.18 & 293 & 210 & 183 & 230 & 230 & 4. 28 \\
\hline & PURE He & 0.83 & 0.16 & 270 & 463 & 443 & 715 & 980 & 8.44 \\
\hline \multirow[t]{5}{*}{$\mathrm{KSN}$} & $\mathrm{He}-2$ & 0.85 & 0.16 & 350 & 129 & 138 & 193 & 263 & 4. 46 \\
\hline & $\mathrm{He}-2$ & 0.80 & 0.20 & 333 & 156 & 156 & 230 & 301 & 4. 67 \\
\hline & VACUUM & 0.79 & 0.20 & 320 & 2150 & 1850 & 7150 & 12500 & 72.47 \\
\hline & AIR & 0.82 & 0.16 & 334 & 93 & 98 & 140 & 185 & 4. 03 \\
\hline & PURE He & 0.82 & 0.17 & 320 & 214 & 200 & 341 & 500 & 5.78 \\
\hline
\end{tabular}

* No and $N_{f}$ were defined as the cycles when the peak tensile stress was reduced to 0.9 and 0.5 of the steady state values, respectively ** $N_{c}$ was the cycles when the slope of elastic portion in tensile side of stress-strain hysteresis loop was reduced to 0.9 of the steady *** state value.

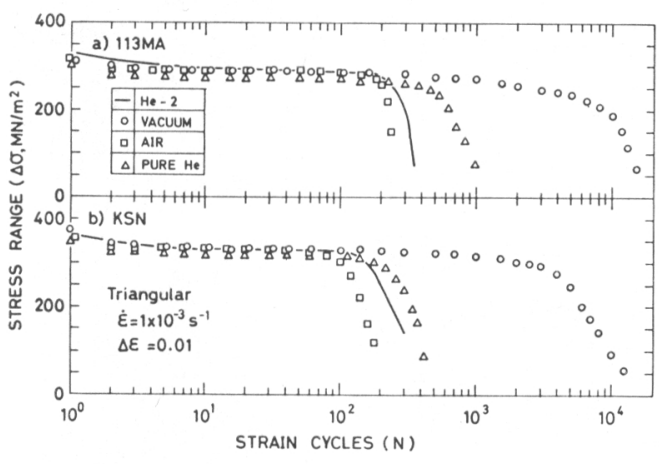

Fig. 6. Changes in stress range $(\Delta \sigma)$ of KSN and 113MA with increasing strain cycles $(N)$ at $1273 \mathrm{~K}$ in various environments.

\section{$3 \cdot 2$ 各種環境下における低サイクル疲労挙動}

本節では，純 $\mathrm{He}$ 中，真空中，大気中において $\Delta \varepsilon_{t}=$ 0.01 で行つた試験結果を第 $2 \mathrm{He}$ 中の結果と比較して 述べる. Fig. 6 には種々の環境下で得られた $\Delta \sigma$ と $N$
の関係を示した・両合金とも試験初期と定常時における $\Delta \sigma$ の挙動には環境の影響が洼とんど現れていない。し かしその後の $\Delta \sigma$ の低下は大気中で最も早期に起こり, ついで第 $2 \mathrm{He}$, 純 $\mathrm{He}$, 真空中の順であつた. 特に真 空中では, $\Delta \sigma$ の急激な減少が起こる以前にゆるやかな 応力低下が認められた。

環境を変光た試験の結果をまとめて Table 4 亿示し た. $N_{\sigma}$ と $N_{c}$ は試験中に引張応力と応力・ひずみルー プの引張側立下り部の傾きがそれぞれ定常時の $90 \%$ に 低下した時のくり返し数であり, $N_{t}$ と $t$ は試験終了時 までの全くり返し数と全試験時間である. 同一環境下で $N_{f}$ を比較すると, KSN より $113 \mathrm{MA}$ の方が長いが, このような合金間の差より環境を変えた場合の差の方が はるかと大きい、すなわち， 3 種類のガス環境下での $N_{f}$ の序列は大気中, 第 $2 \mathrm{He}$ 中, 純 $\mathrm{He}$ 中の順に長く なつたが,それぞれの差は大きくなかつた。一方, 真空 中の $N_{f}$ は飛び好て長く, 大気中の約 50 倍に達して 
いた。

次に $N_{c}$ を見ると，ガス環境での両合金の $N_{c} / N_{f}$ の 值はほとんどの場合 0.6 0.7 の間にあるが，真空中で は $113 \mathrm{MA}$ で 0.13 , KSN で 0.30 と小さい值を示し た. 後述するが, ガス環境では試験中における組織変化 が小さいため, 上記の值は疲労破壊の開始に対応してい ると考光られ, MAIYA ら ${ }^{11}$ が 304 鋼について求めた值 とよく一致している. しかし, 真空中のそれは長時間の 試験による組織変化と Cr の蒸発のため, 早期に強度低 下が起こり小さな值になつたと考壳られる.

さらに注目すべきことは， $N_{c}$ と $N_{\sigma}$ の值がよい一致を 示している点である.このことは, 本実験条件下では疲労 き裂の発生くり返し数が、コンプライアンスの変化と引 張荷重の低下の両方から推定できることを示している.

SEM による破面観察の結果を Photo. 2 に示寸. 破 面上の微細組織は異なつているが, 第 $2 \mathrm{He}$ 中で観察さ れた粒界破壊は大気中および純 $\mathrm{He}$ 中でも認められた。 純 He 中のような比較的長寿命の条件下では, 結晶粒界 上に変形の痕跡が見られるが, 全般的には粒界はく離が 顕著であつた.これに対して真空中の破面は, 両合金とも 全面にわたつてディンプルをともなつた粒内延性破壊で あり, 疲労破壊におよぼす試験環境効果の機構が, 真空中

$\mathrm{He}-2$
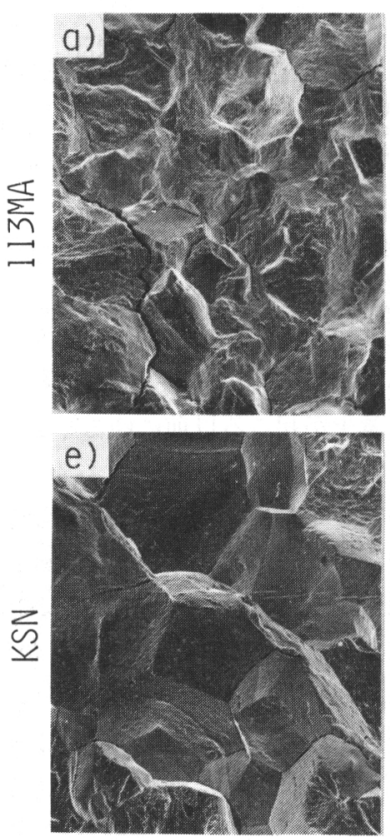

VACUUM
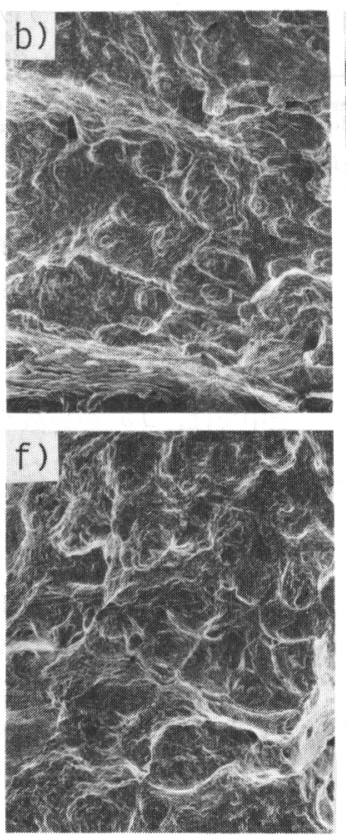

とガス環境中で大きく異なつていることを示していた。

\section{3 疲労試験による組織変化と腐食}

Photo. 3 に真空中で破断した KSN と $113 \mathrm{MA}$ の縦 断面の SEM 写真を示す. 他の 3 種のガス環境下では試 験時間が短いため, 組織変化は顕著ではなからた。試験 片内部に分布している白色の粒子は $\alpha_{2}$ 相 (bcc-W) で ある. 分布形態は $113 \mathrm{MA}$ よりも KSN の方が微細で あるが，両合金とも表面近傍に $\alpha_{2}$ 相の欠乏層が生じて いる. Fig. 7 には Photo. 3,a) 113 MA の深さ方向の $\mathrm{Ni}, \mathrm{Cr}, \mathrm{W}, \mathrm{Ti}$ の濃度分布を示した。試料表面近傍に おいて $\mathrm{Cr}$ 濃度の著しい低下が認められた。この現象は 相対的に母相内のWの固溶限を増大させるため， $\alpha_{2}$ 相 の再固溶が起こり, 結果として表面近傍に $\alpha_{2}$ 相の欠乏 層が生成したと考觉られる12).

このよらに, 表面近傍の組織変化は $\mathrm{Cr}$ の挙動に支配 されていると考学られるので, Fig. 8 には種々の環境 で破断した試料の Cr 濃度の分布を示した．KSN，113 MA とも真空中と純 $\mathrm{He}$ 中では表面に腐食生成物は認 められず金属光沢であつたが，第 $2 \mathrm{He}$ 中と大気中では 腐食により Cr の酸化皮膜が合金表面に生成した：表面 近傍の Cr 濃度の低下は, 第 $2 \mathrm{He}$ 中と大気中では明 らかに腐食によるものであるが，最も激しい低下を示し

a) $113 \mathrm{MA}, \mathrm{He}-2$, b) $113 \mathrm{MA}$, vacuum, c) $113 \mathrm{MA}$, air, d) 113MA, pure $\mathrm{He}$, e ) $\mathrm{KSN}, \mathrm{He}-2$,

f) $\mathrm{KSN}$, vacuum, g) $\mathrm{KSN}$, air and h) KSN, pure He.

AIR
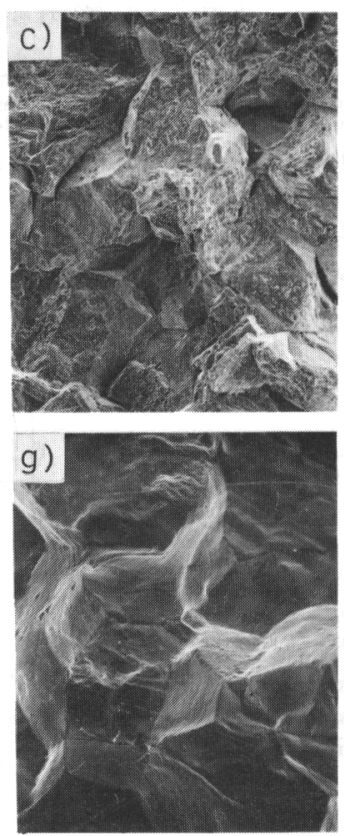

PURE He


Photo. 2. Fractographical results for $\mathrm{KSN}$ and $113 \mathrm{MA}$ after fatigue tests at $\Delta \varepsilon_{t}=0.01$ with triangular waves at $1273 \mathrm{~K}$ in various environments. 

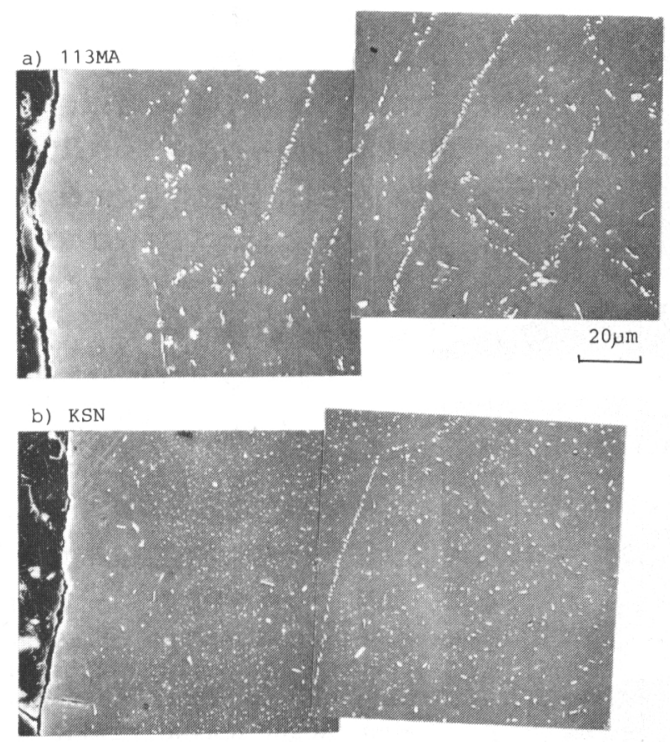

Photo. 3. Microstructures on the cross sections of 113MA and KSN after fatigue tests at 1273 $\mathrm{K}$ in vacuum.

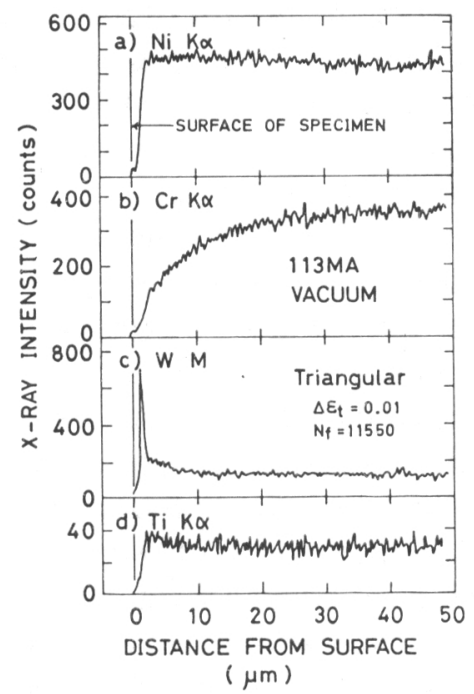

Fig. 7. Characteristic $\mathrm{X}$-ray intensity profiles of $\mathrm{Ni}, \mathrm{Cr}, \mathrm{Ti}$ and $\mathrm{W}$ on the cross section of $113 \mathrm{MA}$ after fatigue test at $1273 \mathrm{~K}$ in vacuum of $1 \times 10^{-6}$ $\mathrm{Pa}$.

た真空中の場合は, $1273 \mathrm{~K}$ における試験中に $\mathrm{Cr}$ が蒸 発したためである。また純 He 中ではこのよらな変化は 全く認められなからた。

Cr の挙動に起因した組織変化や腐食は, くり返し変 形や疲労き裂の発生挙動に影響を与えると思われるの で, 破断後の試験片全体をSEM で観察し, 結果を

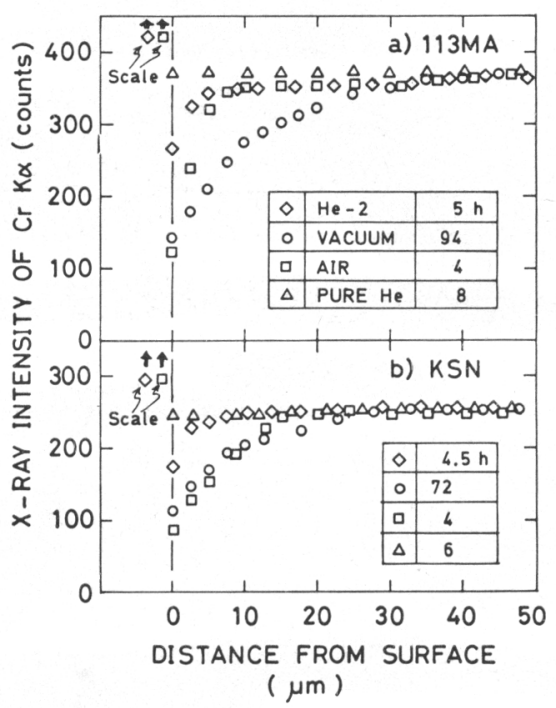

Fig. 8. Effects of environments on a characteristic X-ray intensity profile of $\mathrm{Cr}$ on the cross sections of 113MA and KSN after fatigue tests at $1273 \mathrm{~K}$.

Photo. 4 に示した. ガス環境中試験の代表として第 2 $\mathrm{He}$ 中の $113 \mathrm{MA}$ の例を示したが, 試験片表面は非常 に平滑であり，巨視的な変形の痕跡は認められない。そ して主き裂以外には大きなき裂は発見できなかつた。一 方，真空中で試験した合金の表面は変形にともなら凹凸 があり，その程度は試験片平行部の形状を変えるほど大 きい.また小さな表面き裂が変形帯の凹部に沿つて数多 く発生しているのが観察された.

\section{4. 考察}

$\mathrm{Ni}-\mathrm{Cr}-\mathrm{W}$ 合金 KSN と $113 \mathrm{MA}$ の低サイクル疲労 特性, 特に破断寿命 $\left(N_{f}\right)$ と破壞形態試験環境に依存 して著しく変化した. 同一環境で比較すると，KSN と $113 \mathrm{MA}$ の $N_{f}$ に差が認められたが,これは合金の強 度の違いに起因するものであろら，同一合金系で試験条 件が等しい場合， $\Delta \sigma$ が小さい方が疲労き裂の発生と伝 播に対して有利であると考皇ることができる。これに対 し, 本実験で示された大きな試験環境効果は, それぞれ の合金について力学的条件の等しい場合に現れたものな ので, 金属組織学的な解析が必要である.Fig. 9 には 種々の環境で得られた結果を模式的に示した. 結果は二 つに大別することができる、一つは第 $2 \mathrm{He}$ などのガス 環境下のデータであり比較的短寿命と顕著な粒界破壊で 特徴づけられ, 他の一つは真空中データであり長寿命之 粒内破壊で特徵づけられる。以下に, この二つの場合の 


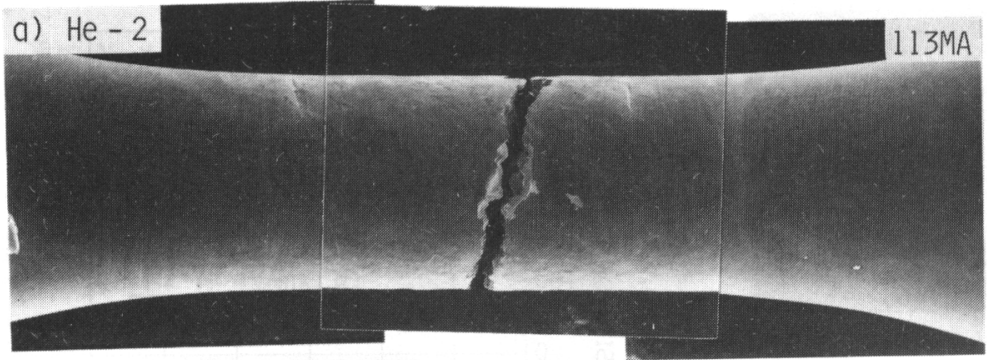

b) VACUUM

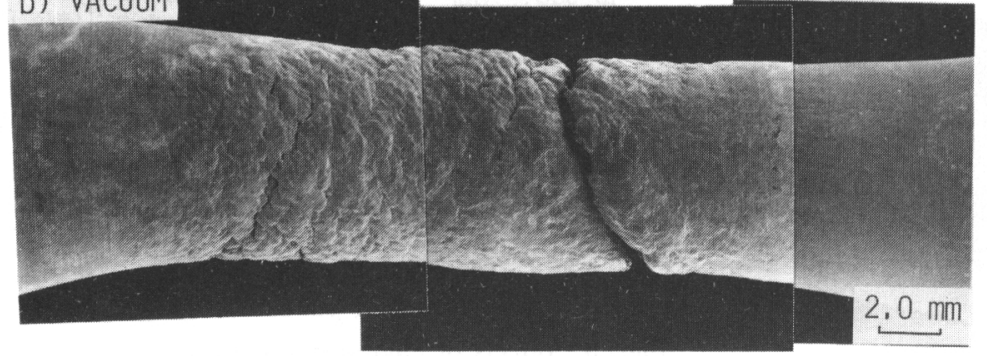

a) in $\mathrm{He}-2$ and b) in vacuum. Photo. 4. SEM photographs for the profile of 113MA specimens after fatigue tests at $1273 \mathrm{~K}$.

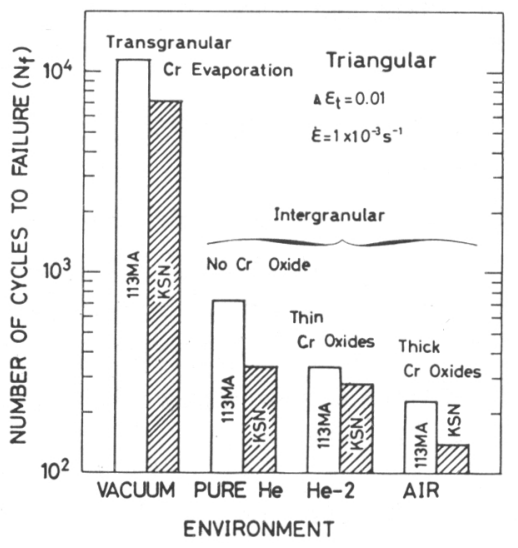

Fig. 9. Schematic figure for the present results obtained from low cycle fatigue specimens tested in various environments.

疲労破壊について考察を試みる.

3 種のガス環境下での $N_{f}$ を比較すると, 大気中, 第 $2 \mathrm{He}$ 中, 純 $\mathrm{He}$ 中の順に長寿命之なり, この傾向は 明らかに環境中に含まれる活性ガス濃度の順番と逆にな つている. しかし, 大気中と第 $2 \mathrm{He}$ 中で試験した試験 片表面には強固な $\mathrm{Cr}$ 酸化物が生成し, 環境が腐食を通 して影響を与えたことを示していたが，純 $\mathrm{He}$ 中の場合 は顕著な腐食は認められず, 試験環境の効果は複雑であ つた.

KSN と $113 \mathrm{MA}$ の腐食挙動に関しては, 第 $2 \mathrm{He}$ 中 $1273 \mathrm{~K}$ で $1000 \mathrm{~h}$ 腐食した場合の結果がすでに報告さ れている13)。それによれば，両合金とも試料表面には
Cr 酸化物皮膜が生成したが, さらに結晶粒界に沿つて 約 $130 \mu \mathrm{m}$ の深さまで $\mathrm{Ti}$ の内部酸化物が認められた。 そして腐食の機構は, 酸素分圧の比較的高い試料表面で まず $\mathrm{Cr}$ が酸化するが，微量の酸素はさらに結晶粒界に 沿つて優先的に侵入し，そこで $\mathrm{Cr}$ 上り親和力の強い $\mathrm{Ti}$ と反応した, と考兄られた。本実験の場合, 試験時 間が短いため粒界内部酸化物は認められなかつたが, 上記の結果は $\mathrm{KSN}$ と $113 \mathrm{MA}$ の疲労挙動に拈上活す腐 食の効果を考光る時, 表面酸化皮膜ばかりでなく, 内部 の結晶粒界に侵入した酸素の効果を考兄る必要があるこ とを示している.

一般に金属材料の高温破壊は, 転位や粒界のすべり変 形にともなつて発生した原子空孔や空洞の挙動の影響を 受ける. WELLS ${ }^{14)}$ とよれば, これらの空孔や空洞は高温 で拡散し, 結晶粒界などで容易に不純物と結合し, 安定 化し，微小き裂の核になると考兄られている. この不純 物之して上記の侵入酸素原子を考克ると, 本実験の結果 は合理的に説明される. 大気中や第 $2 \mathrm{He}$ 中ではもちろ んであるが, 純 $\mathrm{He}$ 中でも最大 $10^{-2} \mathrm{~Pa}$ 程度の分压の 不純物が含まれていると考党られ，その中に含まれる微 量の酸素が，環境側から合金の粒界に侵入し，粒界き裂 の発生と伝播を促進したと思われる. 純 He 中で試験片 表面に $\mathrm{Cr}$ 酸化皮膜が生成しなかつた理由は, 単に酸化 ポテンシャルか゚ $\mathrm{Cr}$ 酸化物生成のそれより低かつただけ であり, 微量酸素の挙動は他の環境と同様であ万う.

次に, 真空中の疲労挙動を見ると, 大きな影響因子と して試験環境中の活性残留ガス分圧の低さと $\mathrm{Cr}$ の蒸発 
を考えることができる．本実験の真空度は $10^{-6} \mathrm{~Pa}$ と， 他の試験環境よりはるかに低い酸素ガス分圧であり, 試 験片に吸収される酸素量は非常に少ないと考えられ，真 空中で長寿命となることは容易に予測できる.しかしな がら，破壊形態の決定的な違いまで含めて説明すること はむずかしい，そこで，さらに Cr の蒸発を考慮して以 下のよらに考察することができよう．環境から合金表面 に侵入しようとする酸素原子は, 活発な $\mathrm{Cr}$ の蒸発によ り阻止され，Gr 蒸気と反応して放出される.このため 表面は常に清浄であり, 結晶粒界に沿つた酸素の侵入 と, それにともなら粒界空孔の安定化は起こらない。一 方, Cr の蒸発は表面近傍の濃度低下をもたらすため, 局部的な変形応力も低下する. 以上二つの効果が重畳 されるため, 真空中においては粒界破壊は起こらず, Photo. 4, b) に見るよらな顕著なすべり変形と, ディン プルをとすなつた粒内延性破壊を起こすと考えられる.

\section{5. 結言}

我が国で開発された 2 種類の Ni-Cr-W 合金 (KSN そ $113 \mathrm{MA}$ ) について, 高温ガス炉近似一リウム（第 2 $\mathrm{He})$ 中, $1273 \mathrm{~K}$ における低サイクル疲労挙動を調べ, その結果を純へリウム中, 大気中, 真空中の結果と比較 し，以下の結論を得た.

(1) 第 $2 \mathrm{He}$ 中において, 合金は全くくり返し硬化 せず，短い定常的くり返し変形の後破断した. KSN と $113 \mathrm{MA}$ の疲労寿命を比較すると, $113 \mathrm{MA}$ の方が長い が，その絶対值は両合金とも全ひずみ幅が 0.01 の時 200〜350 回と短かつた.

（2）疲労破壊は両合金ともすべて粒界で起こつてお り, 粒界の脆化傾向が寿命に影響を与えていると考えら れた.しかし，この傾向は材料の特性のみに依存するる のではなく, 試験環境と密接に関係した挙動であつた。

(3) すなわち, KSN と $113 \mathrm{MA}$ を純 $\mathrm{He}$ 中, 大 気中, 真空中において第 $2 \mathrm{He}$ 中と同様の実験を行ら と, 3 種のガス環境下ではいずれる粒界破壊し, 疲労寿 命は短かつた. しかし, 真空中では粒内延性破壊を起こ
し，長寿命であつた.

（4） ガス環境下での粒界破壊は, 環境中の残留酸素 ガスが合金の結晶粒界に沿つて侵入する効果を考慮する と合理的であり, 真空中では Gr の蒸発によりそれが阻 止されると考えられた。

本研究で使用した合金は, 通産省工業技術院大型プロ ジェクト「高温還元ガス利用による直接製鉄技術の研究 開発」において開発されたもので，KSN は (株) 神戸製 鋼所, $113 \mathrm{MA}$ は日立金属(株)より提供された. 関係各 位に謝意を表します。 また, 本研究の遂行にあたり御指 導いただいた元当所科学研究官故内山郁博士に深く感謝 いたします。

\section{交献}

1) Proc. 2nd US-Japan Seminar on HTGR Safety Technology, 日本原子力研究所 (1978)

2 ) 太田定雄, 青田健一，元田高司：鉄と鋼，65 (1979), p. 1031

3 ) 渡辺力蔵, 千葉芳孝: 鉄之鋼, 63 (1977), p. 118

4 ) L. F. Coffin: Metall. Trans., 3 (1972), p. 1777

5 ) $K$. Furuya, $N$. Nagata and $R$. Watanabe: J. Nucl. Mater., 89 (1980), p. 372

$6) T$. Hirano, $M$. Okada, $H$. Araki, $T$. Noda, $H$. Yoshida and $R$. Watanabe: Metall. Trans., 12A (1981), p. 541

7 ) 新藤雅美, 近藤達男: 鉄と鋼, 62 (1976), p. 1540

8 ) 阿部富士男, 坂井義和, 田辺龍彦, 鈴木 正, 吉 田平太郎：鉄と鋼, 68 (1982), S 1354

9 ) $J . T$. Berling and T. Slot: Fatigue at High Temperatures, STP 459 (1969), p. 3 [ASTM]

10) 平川賢爾, 時政勝行, 外山和男: 鉄之鋼, 65 (1979), p. 184

11) P. S. MaiYa: Scripta Metall., 9 (1975), p. 1141

12）阿部冨士男, 坂井義和, 田辺龍彦, 荒木 弘, 鈴 木 正, 吉田平太郎, 渡辺亮治: 鉄と鋼, 68 (1982), p. 2531

13) $K$. Furuya, $T$. Hirano, $T$. Kainuma and $H$. Yoshida: Proc. 3rd JIM Intern. Symp. on High Temp. Corrosion of Metals and Alloys (1983), p. 547

14) C. H. Wells: Fatigue and Microstructure (1979), p. 307 [ASM] 